\title{
Effect of Growing Media, Sowing Depth, and Hot Water Treatment on Seed Germination and Seedling Biomass of Acacia senegal (L) Wild
}

\author{
Tigist Kibru $^{1^{*}}$, Solomon Zewdie ${ }^{2}$, Abdella Gure $^{2}$ and Tesfaye Gebre ${ }^{1}$ \\ ${ }^{1}$ Department of Land Resources Management and Environmental Protection, Mekelle University, \\ P.O. Box: 231, Mekelle, Ethiopia \\ ${ }^{2}$ Department of Natural Resources Management, Wondo Genet College of Forestry and Natural Resources, \\ Hawassa University, Ethiopia
}

\begin{tabular}{|c|c|}
\hline Abstract & \\
\hline \multirow{14}{*}{$\begin{array}{l}\text { To optimize seedling production for reforestation of degraded dryland with } A \text {. senegal seeds, a } \\
\text { study was conducted on the effect of boiled water treatment, growing media, sowing depth on } \\
\text { seed germination and seedling growth of } A \text {. senegal. Three different growing media (farm soil, } \\
\text { forest soil and sand soil), boiled water seed pre-treatment for } 5 \text { and } 10 \text { minutes, untreated } \\
\text { seeds as control and three sowing depths }(2,4 \text { and } 6 \mathrm{~cm} \text { ) were the treatments investigated. } \\
\text { The experimental design was a nested (Split plot) design. It was observed that sowing depth } \\
\text { significantly affected the germination percent of the seeds and seedling growth; seedling } \\
\text { emergence time increased with sowing depth. The highest cumulative germination percentage } \\
\text { (CGP) ( } 100 \% \text { was obtained from untreated seeds sown in sand soil at } 2 \mathrm{~cm} \text { depth while the } \\
\text { lowest germination percentage }(8 \%) \text { was obtained from seeds pre-treated for } 5 \text { min in boiled } \\
\text { water and sown in sand soil at } 6 \mathrm{~cm} \text { depth. Untreated seeds sown at } 2 \mathrm{~cm} \text { depth in sand soil } \\
\text { germinated completely on the seventh day after sowing while it took about } 17 \text { days in farm and } \\
\text { forest soils but } 18 \text { days in sand soil to reach the maximum recorded CGP for the treatment. } \\
\text { Seedling height and branch number were higher for seedlings grown on forest soil. It was } \\
\text { concluded that among the depths considered } 2 \text { cm was the optimum sowing depth for the } \\
\text { species in all the tested growing media. Likewise, sand soil was found to be the best growing } \\
\text { medium for germination of untreated seeds sown at } 2 \mathrm{~cm} \text { depth. Moreover, seed pre-treatment } \\
\text { for } 5 \text { min in boiled water could be recommended for } A \text {. senegal seeds if farm and forest soil } \\
\text { should be used as growing media. Seedling growth was found to be the best in forest soil } \\
\text { when seeds were sown at } 2 \mathrm{~cm} \text { depth. } \\
\text { Copyright } 2015 \text { STAR Journal, Wollega University. All Rights Reserved. }\end{array}$} & Article History: \\
\hline & Revised : 24-09-2015 \\
\hline & Accepted : 28-09-2015 \\
\hline & Keyn \\
\hline & A. senegal \\
\hline & SowIn \\
\hline & nedia \\
\hline & atment \\
\hline & ermination \\
\hline & growth \\
\hline & ponding $A$ \\
\hline & gist Kibru \\
\hline & \\
\hline & \\
\hline
\end{tabular}

\section{INTRODUCTION}

The genus Acacia is the second largest within the Leguminosae family (sub family Mimosoidae) (Chikamai, 1996) with an estimated 1380 species distributed worldwide (Maslin et al., 2003). Among these, A. senegal and $A$. seyal remain the two most commercially important species (Cossalter, 1987) mainly for their gum produce (FAO, 1995). The majority of gum arabic that enters international trade originates in a region called the "gum belt' of Sub-Saharan Africa; an area that extends from the northern parts of West Africa eastwards to Sudan and Ethiopia (Brockwell et al., 1995; Chikamai, 1996).

Several Acacia species have multiple uses and values. Some are locally utilized while others are of high commercial economic importance. Trees of the genus Acacia are key elements in African savannas where people value them for purposes such as provision of feed and shelter for mammals, birds (Houerou, 1980; Reid and Ellis, 1995; Or and Ward, 2003; Loth et al., 2005), and insects (Kruger and McGavin, 1998), used as soil fertility improver, in soil conservation and for agro-forestry (Milimo et al., 1994; Abd El-Hafiz, 2001). They are also important sources of firewood and charcoal (Hocking, 1993). The wood is generally hard and dense, this makes it very good source for charcoal and fuel wood. Woods of Acacia burns slowly and produces little smoke when dry (Maydell, 1990; Hatab, 2005). Moreover, they are used for house construction, manufacturing of furniture, tools and implements (Maydell, 1990; Springuel and Mekki, 1994). Leaves, bark, gum, roots, pods and seeds are used medicinally against a wide variety of diseases, wounds and burns or dyes (Hocking, 1993). During dry seasons when other feed sources are scarce forage is available from most of Acacia species which are important fodders both for domestic and wild animals (Roshetko, 2001; Hatab, 2005). The seeds are high in crude phosphorus, an element usually scarce in grasslands (Roshetko, 2001).

Through the years, the dryland ecosystems have been subjected to the combined effects of extended droughts and excessive exploitation of natural resources by man and livestock. Increasing frequency of recurrent droughts and excessive exploitation of the resources resulted in increasing pressure on the ecosystem in general and gum trees in particular (Danthu et al., 1992). Owing to 
Tigist Kibru et alo,

increasing anthropogenic pressure, natural woodlands of A. senegal are rapidly disappearing. One practical solution to curb this problem can be large scale domestication of the species through afforestation which can be used as an alternative source for extraction of gum arabic. In recent years, reforestation of the species has been carried out by governmental and NGOs in Amhara and Tigray regional states (Wubalem et al., 2007). Seedlings for large scale reforestation programs need to be produced in large scale. However, for mass production of the seedlings problems associated with seed germination and successful implementation of such an approach presupposes understanding of the germination ecology of the species and improving the germination success of its seeds.

To date, although a number of works have been carried out by several authors on appropriate pre-sowing seed treatments of the species, no information is available on the effect of sowing depth, soil substrate mixtures on seed germination and seedling growth and establishment of $A$. senegal. Therefore, this study was initiated to evaluate the effect of pre-sowing boiled water seed treatment, soil mixtures and sowing depths on the germination characteristics and growth of $A$. senegal seedlings in the green house. The specific objectives were: (i) to study the effect of pre-sowing hot water treatment of $A$. senegal seeds on germination characteristics and seedling growth; (ii) to compare the effect of different soil mixture types on germination characteristics and seedling growth of $A$. senegal; (iii) to find out the influence of seed sowing depth on the germination characteristics and seedling growth of $A$. senegal; and (iv) to identify the optimum treatment combinations (seed treatment, sowing depth and soil substrate type) that result in better germination characteristics and seedling growth of $A$. senegal seedlings.

\section{MATERIALS AND METHODS}

\section{Experimental Site}

The study was conducted at Wondo Genet College of Forestry and Natural Resources laboratory and in a glass house located in the premises of the campus. Wondo Genet is located $263 \mathrm{~km}$ south of Addis Ababa, and about $13 \mathrm{~km}$ south west of Shashemene town.

\section{Seed Characterization}

A. senegal var. senegal seeds were obtained from the Forestry Research Centre (FRC), Ethiopian Institution of Agricultural Research (EIAR), Addis Ababa. The seeds were originally collected from $A$. senegal trees in the Central Rift Valley (around Langano) region of Ethiopia in February 2010.

\section{Procedures and Experimental Design}

In this study, the effect of seed pre-treatment, sowing depths and soil substrates on germination characteristics and seedling growth was investigated on pots under glass house conditions. Seeds were first pre-treated with hot water at $100^{\circ} \mathrm{C}$ for 10 minutes (T1), 5 minutes (T2) and no treatment (T0). These seeds were sown at 3 different soil depths, i.e. $2 \mathrm{~cm}$ (D1), $4 \mathrm{~cm}$ (D2), and $6 \mathrm{~cm}$ (D3) on three different soil substrates filled in pots. The three different soil substrates were farm soil (M1), forest soil (M2) and sand soil (M3). In general, the experiment involved 3 different factors: pre-treatment with boiled water with 3 levels, sowing depth with 3 levels and soil substrate with 3
Sci. Technol. Arts Res. J., July-Sep 2015, 4(3): 47-57

levels; making a total of 27 treatment combinations. The experimental design was a nested design (split plot) where the soil types (substrates) were the main plot factors and combinations of pre-treatment and sowing depth were sub-plots (experimental units) arranged within the main plots. There was a total of 108 sample pots, in each main plot, a total of 36 pots were arranged in 4 replications and 9 rows (pre-treatment versus sowing depth combination treatments). A total of 324 seeds were used for the experiment, 3 seeds per pot were sown.

\section{Pot Preparation and Growth Conditions}

Soils for this study were collected from a maize farm (farm soil) and a nearby natural forest (forest soil). Another type of soil which is texturally sand soil was taken from the nursery site which was deliberately prepared by the nursery site workers. The soils were steam sterilized in a laboratory autoclave (at $121^{\circ} \mathrm{C}$ for 20 minutes) to prevent seed decay due to soil bacteria and fungi. Three different soil substrates were constituted by mixing farm soil, forest soil and sand in different ratio. Farm soil (M1) was constituted solely of farm soil extracted from an agricultural plot. Forest soil (M2) was constituted by mixing a forest and farm soil with sand in 3:2:1 (w/w) proportion while a sand soil (M3) was constituted by mixing sand, farm, and forest soil in 3:2:1 (w/w) proportion. Appropriate numbers of polyethylene bags (12 $\mathrm{cm}$ diameter and $16 \mathrm{~cm}$ length) were filled with soil substrates. Pre-treated seeds were sown at different depths and seeds were allowed to germinate and seedlings to grow. Pots were watered twice a day with tap water until the seeds germinate and watering was continued every other day following germination until the end of the experiment. The mean maximum and minimum temperatures in the course of the experimental period were monitored using a thermometer. The mean maximum and minimum daily temperature in the glass house was 40.6 and $15.1^{\circ} \mathrm{C}$.

\section{Data Collection and Analysis}

The number of germinated seeds was recorded daily from the beginning of germination until no further seed germination occurred. Un-germinated seeds were recorded as failed seeds. The germination criterion was visible protrusion of the cotyledons above the growing media. The following germination characteristics were calculated according to Czabator (1962).

1. Total germination percent $(T G P)=($ Total number of germinated seeds/ total number of seeds) *100

2. Mean daily Germination $(M D G)=$ was calculated as percent of seed germinated on any one day in the course of the experiment divided by the number of days it takes to attain this germination percent.

3. Peak Value $(P V)=$ was computed as the maximum quotient (maximum MDG) derived from the mean daily germination in the course of the experiment.

The growth period of the seedlings was 38 days starting from germination to end of the experiment, and growth parameters were collected such as (seedling height, branch number) at the end of the experiment. Seedling height was measured from the soil line to the tip of a shoot with a ruler. All parameters were subjected to one way and factorial analysis of variance (ANOVA). Statistical analysis was carried out using SAS version 9.0, 
Tigist Kibru et al.,

computer software. P-values were calculated for F-tests of different treatment combinations and mean differences between treatment groups were considered significant at $p<0.05$.

\section{RESULTS}

Effect of Sowing Depth and Pre-Sowing Treatment on Germination Characteristics of $A$. senegal Seeds Sown on Farm Soil

The time course of germination of $A$. senegal seeds subjected to pre-sowing treatment and sown at different soil depths on farm soil is presented in Figure 1. Generally, irrespective of pre-sowing treatments, germination percent and seedling emergence time was higher for seeds sown at $2 \mathrm{~cm}$ depth and decreased with increasing sowing depth. The earliest seed germination was observed on the $4^{\text {th }}$ day after sowing for both the control and pre-treated seeds sown at $2 \mathrm{~cm}$ depth. On the other hand, the lowest and slowest germination was observed for both treated and untreated seeds which
Sci. Technol. Arts Res. J., July-Sep 2015, 4(3): 47-57

were sown at $6 \mathrm{~cm}$ depth. For these groups, by the end of the experiment, final germination percent ranged from 8 to $33 \%$. In contrast, by the end of the experiment, 75 to $83 \%$ of the seeds germinated in the control and those treated for $5 \mathrm{~min}$ (Figure 1).

The effect of pre-sowing treatments and sowing depth on germination characteristics of $A$. senegal seeds sown on farm soil is shown in Table 1. Across germination characteristics, mean values generally declined with increasing sowing depths. In control and 5 min treated seeds sowing depth significantly affected the TGP, and PV of the seeds, while in 10 min pre-treated seeds it has no significant effect on the germination characteristics. In both control and 5 min pre-treated seeds the highest TGP $(75,83.34 \%)$ and PV $(0.12,0.17)$ were found at $2 \mathrm{~cm}$ depth followed by $4 \mathrm{~cm}$ (Table 1). For seeds in the control and those pre-treated for $5 \mathrm{~min}$, seeds sown at $6 \mathrm{~cm}$ soil depth had significantly lower TGP (78 to $90 \%$ lower) than those sown at $2 \mathrm{~cm}$ depth.

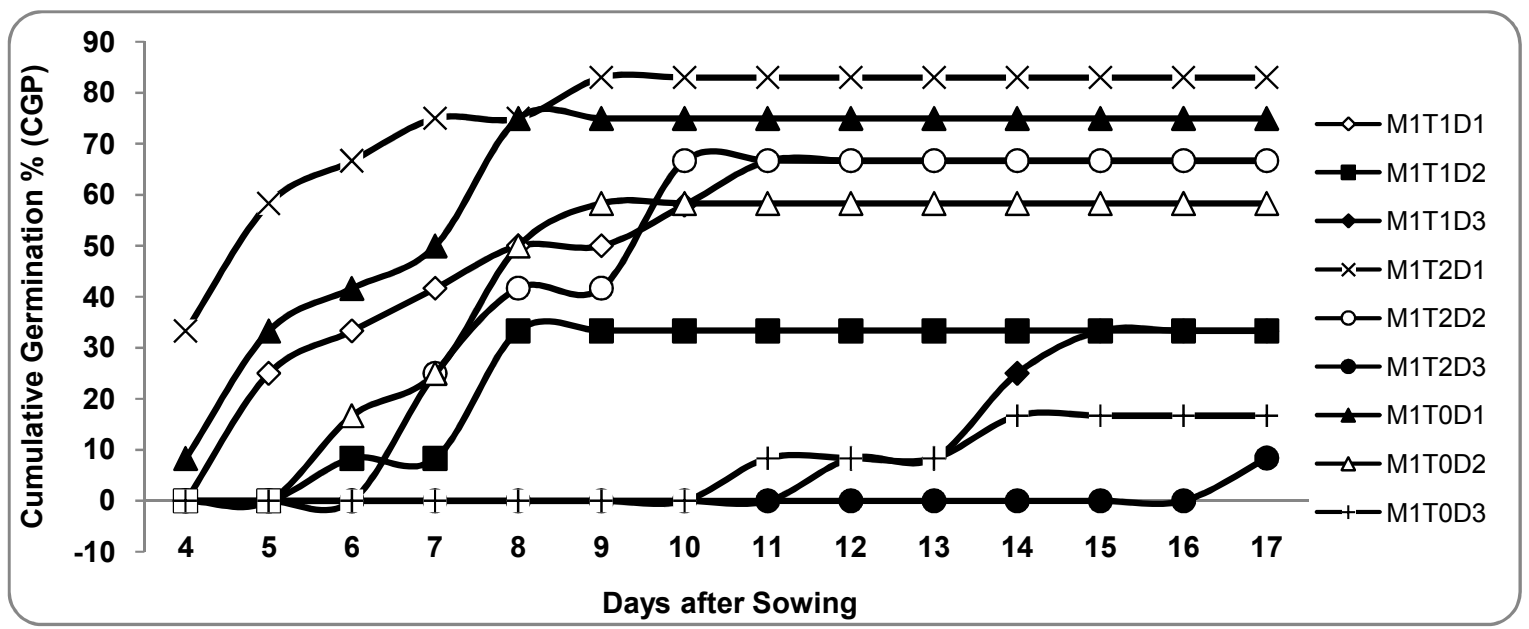

Figure 1: CGP of $A$. senegal seeds subjected to pre-sowing boiled water treatments for different periods and sown at different depths on farm soil

Table 1: Germination characteristics of $A$. senegal seeds subjected to different pre-sowing hot water soaking time and sown at different soil depths on farm soil (M1)

\begin{tabular}{ccccc}
\hline Germination & Sowing & \multicolumn{3}{c}{ Treatments } \\
\cline { 3 - 5 } characteristics & $\begin{array}{c}\text { Copth }(\mathbf{c m}) \\
\text { dentrol }\end{array}$ & $\mathbf{5 ~} \mathbf{~ m i n}$ & $\mathbf{1 0} \mathbf{~ m i n}$ \\
\hline \multirow{2}{*}{ TGP } & 2 & $75.00 \pm 8.33 \mathrm{Aa}$ & $83.34 \pm 9.62 \mathrm{Aa}$ & $66.70 \pm 19.25 \mathrm{Aa}$ \\
& 4 & $58.33 \pm 16.0 \mathrm{Aa}$ & $66.70 \pm 13.61 \mathrm{Aa}$ & $33.33 \pm 13.61 \mathrm{Aa}$ \\
& 6 & $16.70 \pm 9.62 \mathrm{Ba}$ & $8.33 \pm 8.33 \mathrm{Ba}$ & $33.33 \pm 13.61 \mathrm{Aa}$ \\
\hline \multirow{2}{*}{ PV } & 2 & $0.12 \pm 0.01 \mathrm{Aa}$ & $0.17 \pm 0.02 \mathrm{Aa}$ & $0.11 \pm 0.03 \mathrm{Aa}$ \\
& 4 & $0.08 \pm 0.02 \mathrm{Aa}$ & $0.08 \pm 0.02 \mathrm{Ba}$ & $0.05 \pm 0.02 \mathrm{ABa}$ \\
& 6 & $0.01 \pm 0.01 \mathrm{Ba}$ & $0.01 \pm 0.01 \mathrm{Ca}$ & $0.02 \pm 0.01 \mathrm{Ba}$ \\
\hline
\end{tabular}

Values are mean \pm S.E. $n=4$ (experimental units). Means in the same row followed by same lower case letters and means in the same column (for a given germination characteristic) followed by same upper case letter do not differ significantly at $p=0.05$.

Pre-sowing treatment of the seeds has no significant treatment effect on TGP and PV of seeds sown at 2, 4 and $6 \mathrm{~cm}$ depth (Table 1). In seeds sown at $2 \mathrm{~cm}$ depth the highest TGP $(83.34 \%)$ and PV $(0.17)$ was found in 5 min pre-treated seeds followed by control and 10 min pretreated seeds. For seeds sown at $2 \mathrm{~cm}$ depth, PV of seeds pre-treated for 5 min was 29 to $35 \%$ higher than that of the control or those pre-treated for $10 \mathrm{~min}$ in boiled water.
Mean daily germination (MDG) of $A$. senegal seeds in the course of the experimental period is shown in Figure 2 . Mean daily germination reached at peak $(0.12)$ on the 5 th day after sowing for seeds soaked in boiled water for $5 \mathrm{~min}$ and sown at $2 \mathrm{~cm}$ depth. In contrast, mean daily germination of seeds in the control which were sown at the same depth reached at peak (ca. 0.09) on the $8^{\text {th }}$ day. Generally, MDG was lowest for sown at $6 \mathrm{~cm}$ depth. For most of the treatments, MDG remained constant after day 9 until the end of the experiment (Figure 2). 


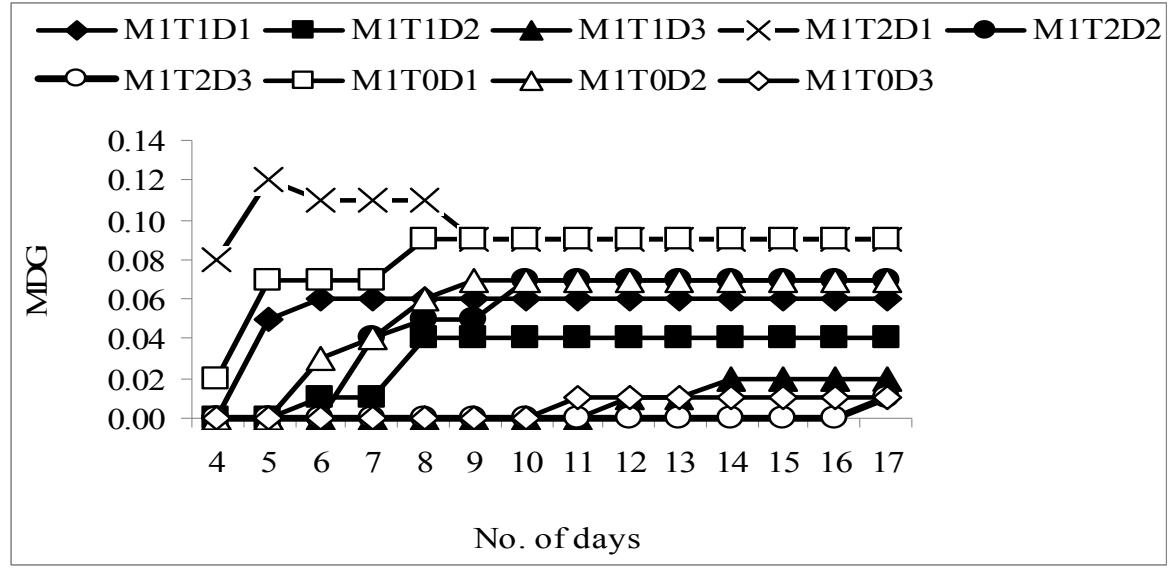

Figure 2: MDG of $A$. senegal seeds pre-treated with boiled water and sown at different depths on farm soil

Effect of Sowing Depth and Pre-Sowing Treatment on Seedling Height and Number of Branches of $A$. senegal Seedlings Sown on Farm Soil

For both growth parameters, mean values generally declined with increasing sowing depths (Table 2). In control and 5 min pre-treated seeds sowing depth significantly affected height of the seedlings, number of branches of the seedlings was a significantly affected by sowing depth only in control seeds. Sowing depth has no significant effect on the growth of $10 \mathrm{~min}$ pre-treated seeds. In 5 min pre-treated seeds sown at $6 \mathrm{~cm}$ depth seedlings were not survived. In both control and pretreated seeds the highest seedling height and branch number was recorded at $2 \mathrm{~cm}$ depth, and $4 \mathrm{~cm}$ depth has higher seedling height and branch number than $6 \mathrm{~cm}$ depth.

Pre-sowing treatment of the seeds has no significant treatment effect on the growth of the seedlings grown at 2 and $4 \mathrm{~cm}$ depth but at $6 \mathrm{~cm}$ depth pre sowing treatment of the seeds has significant negative effect on the growth of the seedlings (Table 2). There was no any seedling grown recorded from 5 min pre-treated seeds sown at $6 \mathrm{~cm}$ depth. Generally, seedlings emerged from untreated seeds were taller and had higher number of branches than those that emerge from treated seeds (Table 2).

Table 2: Growth of $A$. senegal seeds subjected to different pre-sowing hot water soaking time and sown at different soil depths on farm soil (M1)

\begin{tabular}{ccccc}
\hline Growth & Sowing & \multicolumn{3}{c}{ Seed treatments } \\
\cline { 3 - 5 } parameters & depth $(\mathbf{c m})$ & Control & $\mathbf{5}$ min & $\mathbf{1 0 ~}$ min \\
\hline \multirow{2}{*}{$\begin{array}{c}\text { Seedling } \\
\text { height }(\mathrm{cm})\end{array}$} & 2 & $17.50 \pm 0.64 \mathrm{Aa}$ & $13.44 \pm 1.48 \mathrm{Aa}$ & $15.30 \pm 2.02 \mathrm{Aa}$ \\
& 4 & $13.54 \pm 1.14 \mathrm{Ba}$ & $9.57 \pm 3.44 \mathrm{Aa}$ & $12.67 \pm 2.09 \mathrm{Aa}$ \\
& 6 & $7.00 \pm 0.00 \mathrm{Ca}$ & - & $6.60 \pm 0.00 \mathrm{Ab}$ \\
\hline \multirow{2}{*}{ Number of } & 2 & $21.75 \pm 2.14 \mathrm{Aa}$ & $18.2 \pm 3.67 \mathrm{Aa}$ & $19.67 \pm 2.40 \mathrm{Aa}$ \\
branches & 4 & $16.00 \pm 1.87 \mathrm{ABa}$ & $14.0 \pm 3.79 \mathrm{Aa}$ & $17.00 \pm 2.00 \mathrm{ABa}$ \\
& 6 & $10.00 \pm 0.00 \mathrm{Ba}$ & - & $8.00 \pm 0.00 \mathrm{Bb}$ \\
\hline
\end{tabular}

Values are mean \pm S.E. $n=4$ (experimental units). Means in the same row followed by same lower case letters and means in the same column (for a given growth parameter) followed by same upper case letter do not differ significantly at $p=0.05$.

Effect of Sowing Depth, and Pre Sowing Treatment on Germination Characteristics of $A$. senegal Seeds Sown on Forest Soil

The time course of germination of $A$. senegal seeds subjected to different pre-sowing treatment in boiled water and sown at different soil depths on forest soil is presented in Figure 3 . Irrespective of the pre-sowing treatments, germination percent and seedling emergence time was higher for seeds sown at $2 \mathrm{~cm}$ depth and declined with increasing sowing depth. The earliest seed germination was observed on the $4^{\text {th }}$ day after sowing for both control and pre-treated seeds sown at $2 \mathrm{~cm}$ depth. For seeds sown at $6 \mathrm{~cm}$ depth, the earliest seed germination was observed on the $7^{\text {th }}$ day. By the end of the experiment, among seeds in the control and those treated for $5 \mathrm{~min}, 83$ to $92 \%$ of them germinated. While, the lowest and slowest germination was observed for both treated and untreated seeds which were sown at $6 \mathrm{~cm}$ depth. For these groups, final germination percent by the end of the experiment ranged 25 to $50 \%$.
Generally, across germination characteristics mean values declined with increasing sowing depths. In control seeds there were no sowing depth effect on TGP of the seeds germinated, while PV of the seeds was significantly affected by sowing depth. The TGP and PV of 5 min pretreated seeds were significantly affected by sowing depth. In $10 \mathrm{~min}$ pre-treated seeds sowing depth has no significant effect on TGP and PV of the seeds. In 5 min pre-treated seeds the highest TGP and PV were obtained at $2 \mathrm{~cm}$ depth $(91.67 \%, 0.17)$ (Table 3$)$.

Pre-sowing treatment of the seeds has no significant treatment effect on TGP and PV of seeds sown at all depth. Seeds in the control and those received 5 min presowing treatment yielded generally higher TGP and PV than those seeds pre-treated for $10 \mathrm{~min}$ in boiled water (Table 3). 


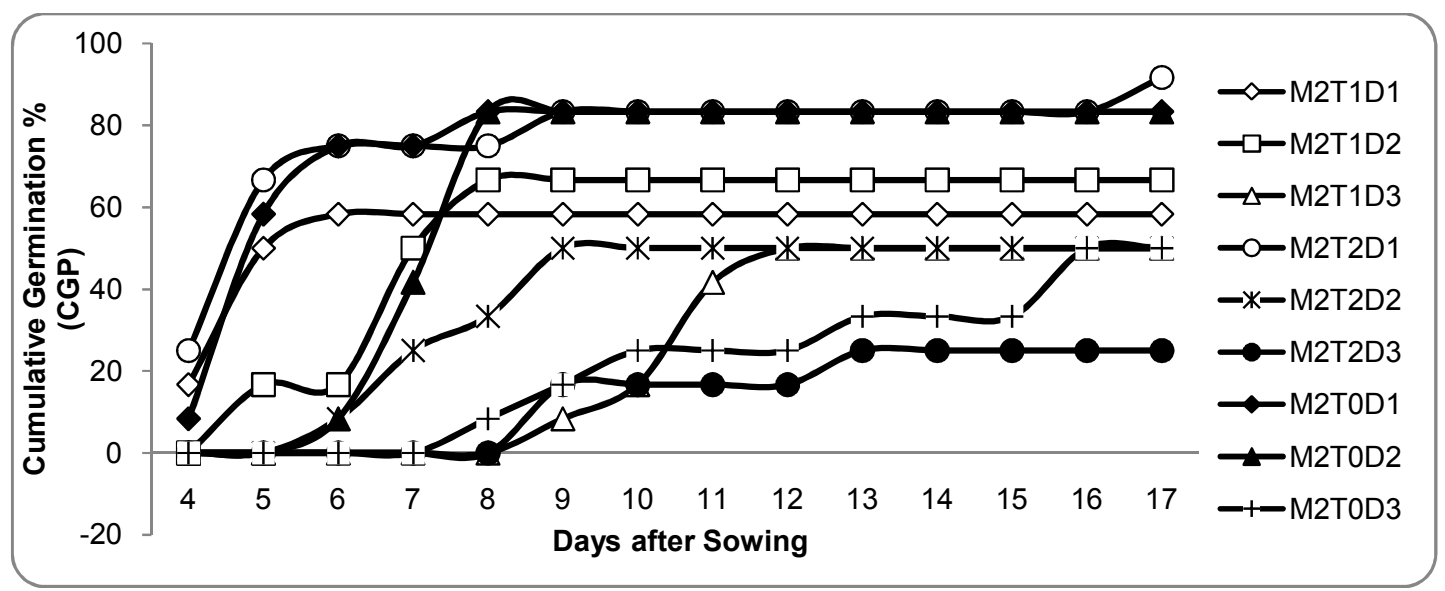

Figure 3: CGP of $A$. senegal seeds subjected to pre-sowing boiled water treatments for different periods and sown at different depths on forest soil

Table 3: Germination characteristics of $A$. senegal seeds subjected to different pre-sowing hot water soaking time and sown at different soil depths on forest soil (M2)

\begin{tabular}{ccccc}
\hline Germination & Sowing & & \multicolumn{3}{c}{ Treatments } \\
\cline { 3 - 5 } Characteristics & depth $\mathbf{( c m})$ & Control & $\mathbf{5 ~ m i n}$ & $\mathbf{1 0}$ min \\
\cline { 3 - 5 } TGP & 2 & $83.34 \pm 9.62 \mathrm{Aa}$ & $91.67 \pm 8.33 \mathrm{Aa}$ & $58.33 \pm 25.00 \mathrm{Aa}$ \\
& 4 & $83.34 \pm 9.62 \mathrm{Aa}$ & $50.00 \pm 9.62 \mathrm{Ba}$ & $66.67 \pm 19.25 \mathrm{Aa}$ \\
& 6 & $50.00 \pm 9.62 \mathrm{Ba}$ & $25.00 \pm 15.96 \mathrm{Ba}$ & $50.00 \pm 21.52 \mathrm{Aa}$ \\
\hline \multirow{2}{*}{ PV } & 2 & $0.16 \pm 0.03 \mathrm{Aa}$ & $0.17 \pm 0.01 \mathrm{Aa}$ & $0.13 \pm 0.06 \mathrm{Aa}$ \\
& 4 & $0.11 \pm 0.01 \mathrm{Aa}$ & $0.07 \pm 0.01 \mathrm{Ba}$ & $0.10 \pm 0.03 \mathrm{Aa}$ \\
& 6 & $0.05 \pm 0.01 \mathrm{Ba}$ & $0.03 \pm 0.02 \mathrm{Ca}$ & $0.05 \pm 0.02 \mathrm{Aa}$ \\
\hline
\end{tabular}

Values are mean \pm S.E. $n=4$ (experimental units). Means in the same row followed by same lowe case letters and means in the same column (for a given germination characteristic) followed by same upper case letter do not differ significantly at $p=0.05$.

Mean daily germination (MDG) of $A$. senegal seeds on forest soil, in the course of the experimental period is shown in Figure 4. Mean daily germination reached its peak $(0.13)$ on the $5^{\text {th }}$ and $6^{\text {th }}$ day after sowing in both 5 min pretreated and control seeds sown at $2 \mathrm{~cm}$ depth respectively. In contrast, MDG of seeds pre-treated for 10 min and sown at the same depth reached its peak (ca. $0.10)$ on the $5^{\text {th }}$ day. Generally, MDG was lowest for seeds sown at $6 \mathrm{~cm}$ depth. In most of the treatments, MDG remained constant after day 9 until the end of the experiment (Figure 4).

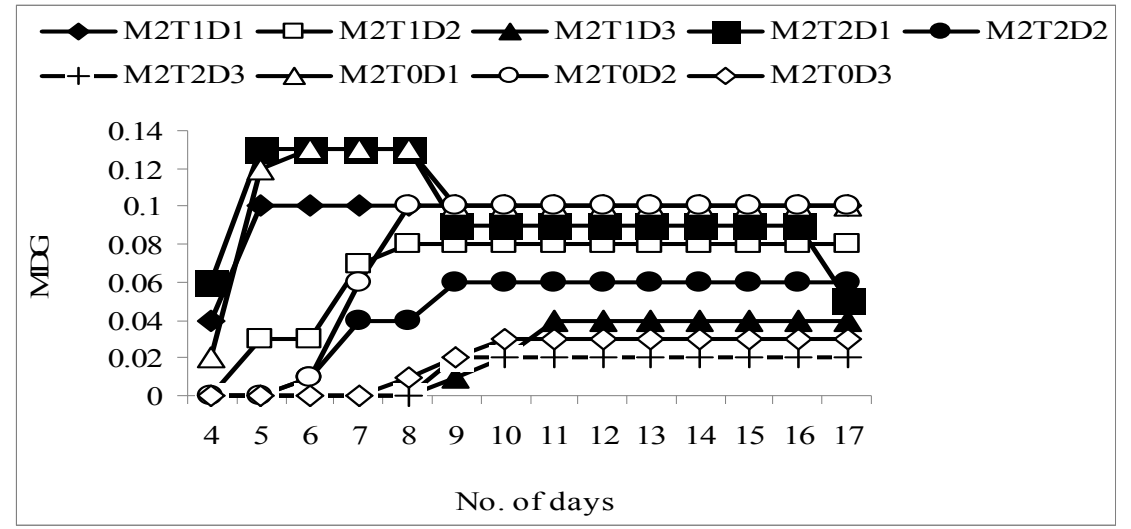

Figure 4: MDG of $A$. senegal seeds sown on forest soil, at different sowing depths and treated in boiled water

Effect of Sowing Depth and Pre-Sowing Treatment on Seedling Height and Number of Branches of $A$. senegal Seedlings Sown on Forest Soil

For both growth parameters, mean values generally declined with increasing sowing depths (Table 4). In both control and pre-treated seeds sowing depth significantly affected the growth of the seedlings. The highest seedling height was recorded at $2 \mathrm{~cm}$ depth in both control and pre-treated seeds and the lowest was recorded at $6 \mathrm{~cm}$ depth.
Pre-sowing treatment of the seeds has no significant treatment effect on the growth of the seedlings grown at all depth except number of branches of the seedlings grown at $4 \mathrm{~cm}$ depth (Table 4). Generally, seedlings emerged from untreated seeds were taller and had higher number of branches than those that emerge from treated seeds. Across sowing depths, seeds that received presowing boiled water treatment for $10 \mathrm{~min}$ were taller and produced higher number of branches than those pretreated for 5 min (Table 4). 
Table 4: Growth of $A$. senegal seedlings emerged from seeds subjected to different pre-sowing hot water soaking time and sown at different soil depths on forest soil

\begin{tabular}{ccccc}
\hline Growth & Sowing & \multicolumn{3}{c}{ Treatments } \\
\cline { 2 - 5 } parameters & depth $\mathbf{( c m})$ & Control & $\mathbf{5 ~} \mathbf{~ m i n}$ & $\mathbf{1 0}$ min \\
\hline \multirow{2}{*}{ Seedling } & 2 & $19.00 \pm 0.88 \mathrm{Aa}$ & $17.46 \pm 0.47 \mathrm{Aa}$ & $18.45 \pm 1.33 \mathrm{Aa}$ \\
height & 4 & $14.60 \pm 1.94 \mathrm{Aa}$ & $11.83 \pm 2.46 \mathrm{Ba}$ & $16.30 \pm 1.28 \mathrm{Aa}$ \\
& 6 & $7.67 \pm 2.84 \mathrm{Ba}$ & $10.53 \pm 1.43 \mathrm{Ba}$ & $9.40 \pm 0.87 \mathrm{Ba}$ \\
\hline \multirow{2}{*}{ Number of } & 2 & $20.20 \pm 2.27 \mathrm{Aa}$ & $22.60 \pm 1.25 \mathrm{Aa}$ & $24.00 \pm 2.08 \mathrm{Aa}$ \\
Branches & 4 & $16.25 \pm 2.06 \mathrm{ABab}$ & $14.00 \pm 3.51 \mathrm{Bb}$ & $23.25 \pm 0.85 \mathrm{Aa}$ \\
& 6 & $8.67 \pm 2.85 \mathrm{Ba}$ & $13.00 \pm 1.73 \mathrm{Ba}$ & $9.50 \pm 1.04 \mathrm{Ba}$ \\
\hline \multicolumn{2}{l}{ Values are mean \pm S.E. $\mathrm{n}=4$ (experimental units). Values are mean \pm S.E. $\mathrm{n}=4$. Means in the } \\
same row followed by same lower case letters and means in the same column (for a given \\
growth parameter) followed by same upper case letter do not differ significantly at $\mathrm{p}=0.05$.
\end{tabular}

Effect of Sowing Depth and Pre-Sowing Treatments on Germination Characteristics of $A$. senegal Seeds Sown on Sand Soil

The time course of germination of $A$. senegal seeds subjected to pre-sowing boiled water treatments for different soaking time and sown at different soil depths on sand soil is presented in Figure 5. Generally, irrespective of pre-sowing treatments, germination percent and seedling emergence time was higher for seeds sown at 2 $\mathrm{cm}$ depth and decreases as the sowing depth increases. The earliest seed germination was observed on the $4^{\text {th }}$ day after sowing for both control and 5 min pre-treated seeds sown at $2 \mathrm{~cm}$ depth. On the $7^{\text {th }}$ day after sowing, ca. $100 \%$ seedling emergence was observed in control seeds sown at $2 \mathrm{~cm}$ depth. For the same date, seeds that received 5 min pre-sowing treatment and sown at $2 \mathrm{~cm}$ depth, $91 \%$ of the seeds germinated. On the other hand, the lowest and slowest germination was observed for both control and 5 min pre-treated seeds which were sown at 6 $\mathrm{cm}$ depth while $10 \mathrm{~min}$ pretreated seeds and sown at 6 $\mathrm{cm}$ depth failed to germinate.

The effect of pre-sowing treatments and sowing depth on germination characteristics of $A$. senegal seeds sown on sand soil is shown in Table 5 . Across germination characteristics, mean values generally declined with increasing sowing depths. Sowing depth has significant effect on TGP and PV of the control and pre-treated seeds. The highest TGP $(100 \%)$ and PV $(0.19)$ was found in control seeds sown at $2 \mathrm{~cm}$ depth followed by 5 and 10 min pre-treated seeds sown at the same depths. Generally $4 \mathrm{~cm}$ sowing depth has better TGP and PV than $6 \mathrm{~cm}$ depth.

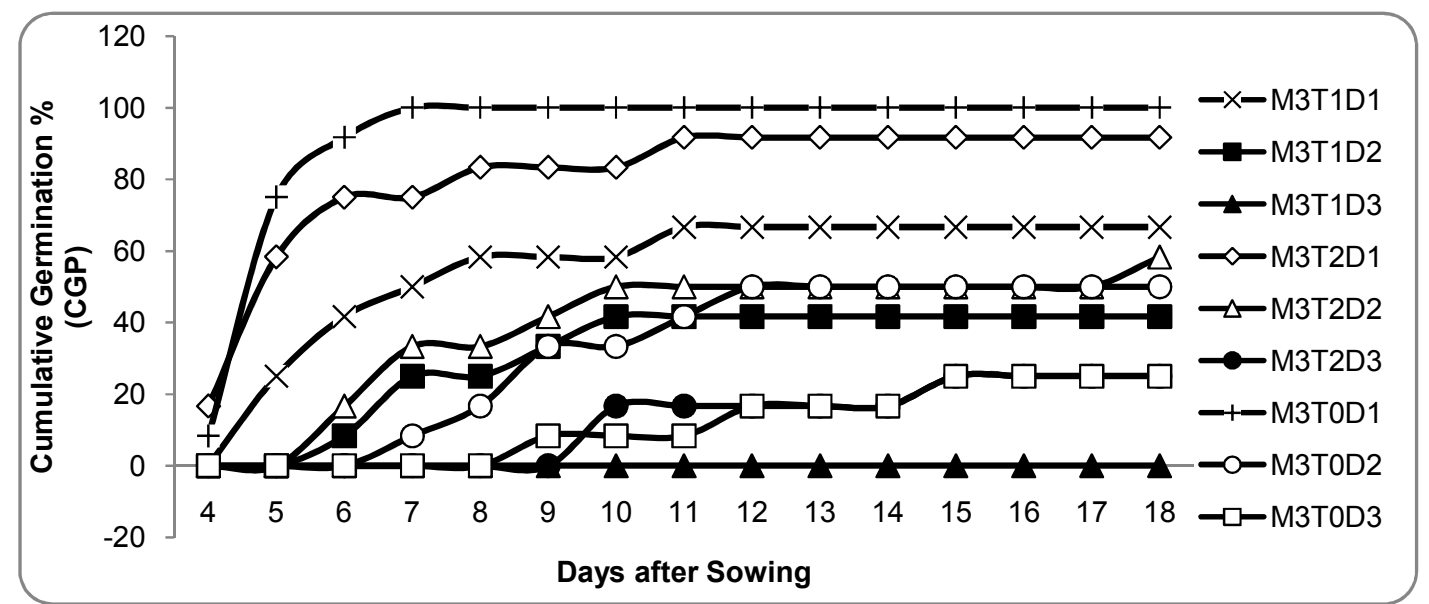

Figure 5: CGP of $A$. senegal seeds subjected to pre-sowing boiled water treatments for different periods and sown at different depths on sand soil

Table 5: Germination characteristics of $A$. senegal seeds subjected to different pre-sowing hot water soaking time and sown at different soil depths on sand soil (M3)

\begin{tabular}{ccccc}
\hline Germination & Sowing & \multicolumn{3}{c}{ Treatments } \\
\cline { 3 - 5 } characteristics & depth $(\mathbf{c m})$ & Control & $\mathbf{5}$ min & $\mathbf{1 0}$ min \\
\hline \multirow{2}{*}{ TGP } & 2 & $100.00 \pm 0.00 \mathrm{Aa}$ & $91.67 \pm 8.33 \mathrm{Aab}$ & $66.67 \pm 13.61 \mathrm{Ab}$ \\
& 4 & $50.00 \pm 9.62 \mathrm{Ba}$ & $58.34 \pm 8.34 \mathrm{ABa}$ & $41.67 \pm 8.34 \mathrm{Aa}$ \\
& 6 & $25.00 \pm 15.96 \mathrm{Ba}$ & $25.00 \pm 15.96 \mathrm{Ba}$ & - \\
\hline \multirow{2}{*}{ PV } & 2 & $0.19 \pm 0.01 \mathrm{Aa}$ & $0.18 \pm 0.02 \mathrm{Aab}$ & $0.11 \pm 0.03 \mathrm{Ab}$ \\
& 4 & $0.06 \pm 0.01 \mathrm{Ba}$ & $0.07 \pm 0.01 \mathrm{Ba}$ & $0.06 \pm 0.01 \mathrm{ABa}$ \\
& 6 & $0.02 \pm 0.02 \mathrm{Ba}$ & $0.02 \pm 0.01 \mathrm{Ca}$ & - \\
\hline
\end{tabular}

Values are mean \pm S.E. $n=4$ (experimental units). Means in the same row followed by same lower case letters and means in the same column (for a given germination characteristic) followed by same upper case letter do not differ significantly at $p=0.05$ 
Tigist Kibru et alo,

Pre-sowing treatment of the seeds has no significant treatment effect on TGP and PV of the seeds sown at different depths. For seeds sown at $2 \mathrm{~cm}$ depth, TGP of control seeds was 8 to $33 \%$ higher than that of 5 and 10 min pre-treated seeds (Table 5 ).

Mean daily germination (MDG) of $A$. senegal seeds germinated on sand soil in the course of the experimental
Sci. Technol. Arts Res. J., July-Sep 2015, 4(3): 47-57

period is shown in Figure 6. Mean daily germination reached a peak $(0.15)$ on the 5th day after sowing in control seeds sown at $2 \mathrm{~cm}$ depth. This was higher than the MDG for the same date for seeds that received presowing treatments $(0.05-0.12)$. Generally, MDG was lowest for seeds in the control and pre-treated ones which were sown at $6 \mathrm{~cm}$ depth.

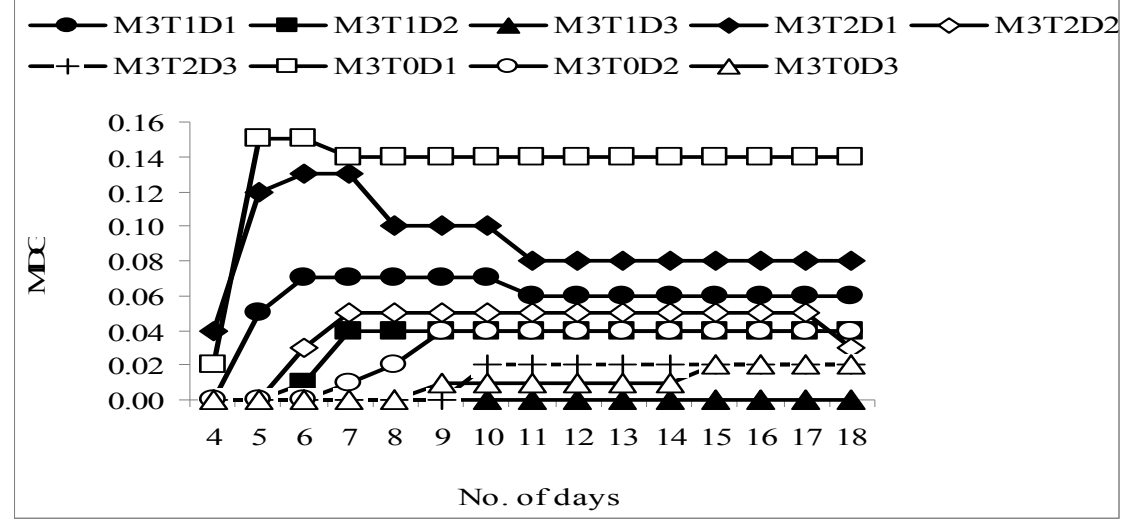

Figure 6: MDG of $A$. senegal seeds sown on sand soil at different sowing depths and treated in boiled water

Effect of Sowing Depth, and Pre-Sowing Treatment on Seedling Height and Number of Branches of $A$. senegal Seedlings Sown on Sand Soil

Across the growth parameters, mean values for seedling height and number of branches generally declined with increasing sowing depths (Table 6). There were significant differences in seedling height among seedlings grown at three depths for 5 and $10 \mathrm{~min}$ pretreated seeds but not for the control groups. In both control and pre-treated seeds highest seedling height and number of branches was found in seedlings grown at 2 $\mathrm{cm}$ depth. In 10 min pre-treated seeds sown at $6 \mathrm{~cm}$ depth there was no recorded seedling emergence due to germination failure of the seeds (Table 6).

There were no significant treatment effects on seedling height and number of branches between seeds sown at 2 $\mathrm{cm}$ and $4 \mathrm{~cm}$ depth. Among those seedlings grown from control and pre- treated seeds and sown at $6 \mathrm{~cm}$ soil depth, 5 min pre-treated seeds had lower number of branches than control seeds (Table 7).

Table 6: Growth of $A$. senegal seeds subjected to different pre-sowing hot water treatments and sown at different soil depths on sand soil

\begin{tabular}{ccccc}
\hline Growth & Sowing & \multicolumn{3}{c}{ Treatments } \\
\cline { 3 - 5 } parameters & depth $(\mathbf{c m})$ & Control & $\mathbf{5}$ min & $\mathbf{1 0}$ min \\
\hline \multirow{3}{*}{ Seedling height } & 2 & $14.03 \pm 1.19 \mathrm{Aa}$ & $14.67 \pm 0.56 \mathrm{Aa}$ & $15.55 \pm 0.96 \mathrm{Aa}$ \\
& 4 & $13.95 \pm 3.15 \mathrm{Aa}$ & $10.87 \pm 1.76 \mathrm{Ba}$ & $15.37 \pm 1.21 \mathrm{Aa}$ \\
& 6 & $14.00 \pm 0.00 \mathrm{Aa}$ & $9.40 \pm 0.60 \mathrm{Bb}$ & - \\
\hline \multirow{3}{*}{ Number of branches } & 2 & $18.83 \pm 1.52 \mathrm{Aab}$ & $16.67 \pm 0.88 \mathrm{Ab}$ & $21.00 \pm 1.47 \mathrm{Aa}$ \\
& 4 & $16.50 \pm 4.50 \mathrm{Aa}$ & $16.00 \pm 4.36 \mathrm{Aa}$ & $20.33 \pm 2.40 \mathrm{Aa}$ \\
& 6 & $13.00 \pm 0.00 \mathrm{Aa}$ & $10.50 \pm 0.50 \mathrm{Ab}$ & - \\
\hline
\end{tabular}

Values are mean \pm S.E. $n=4$ (experimental units). Means in the same row followed by same lower case letters and means in the same column (for a given growth parameter) followed by same upper case letter do not differ significantly at $p=0.05$.

Table 7: Summary of ANOVA results of the effect of growth media, pre-sowing treatment time, sowing depth and their interaction on germination characteristics and seedling growth of $A$. senegal. D- sowing depth; $T-$ pre-sowing treatment time and $\mathrm{M}$ - media

\begin{tabular}{|c|c|c|c|c|c|c|c|c|c|c|c|c|c|c|c|}
\hline \multirow{3}{*}{$\begin{array}{c}\text { Source } \\
\text { of } \\
\text { variation }\end{array}$} & \multicolumn{9}{|c|}{ Germination Characteristics } & \multicolumn{6}{|c|}{ Growth parameters } \\
\hline & \multicolumn{3}{|c|}{ TGP } & \multicolumn{3}{|c|}{ MDG } & \multicolumn{3}{|c|}{ PV } & \multicolumn{3}{|c|}{$\begin{array}{c}\text { Seedling } \\
\text { height }(\mathrm{cm})\end{array}$} & \multicolumn{3}{|c|}{$\begin{array}{l}\text { Number of } \\
\text { branches }\end{array}$} \\
\hline & DF & MS & $\begin{array}{c}p- \\
\text { value }\end{array}$ & DF & MS & $\begin{array}{c}p- \\
\text { value }\end{array}$ & DF & MS & $\begin{array}{c}p- \\
\text { value }\end{array}$ & DF & MS & $\begin{array}{c}p- \\
\text { value }\end{array}$ & DF & MS & $\begin{array}{c}p- \\
\text { value }\end{array}$ \\
\hline $\mathrm{D}(\mathrm{cm})$ & 2 & 26122.3 & $<.00$ & 2 & 0.13 & $<.00$ & 2 & 0.14 & $<.00$ & 2 & 458.2 & $<.00$ & 2 & 855.4 & $<.00$ \\
\hline M & 2 & 1769.6 & 0.08 & 2 & 0.00 & 0.45 & 2 & 0.01 & 0.06 & 2 & 60.3 & 0.00 & 2 & 60.9 & 0.04 \\
\hline$T$ & 2 & 1800.8 & 0.08 & 2 & 0.01 & 0.11 & 2 & 0.00 & 0.09 & 3 & 44.8 & 0.01 & 3 & 22.0 & 0.31 \\
\hline$M * D$ & 4 & 920.7 & 0.26 & 4 & 0.00 & 0.77 & 4 & 0.00 & 0.45 & 4 & 12.3 & 0.22 & 4 & 17.6 & 0.44 \\
\hline$T^{\star} \mathbf{D}$ & 4 & 859.1 & 0.30 & 4 & 0.01 & 0.10 & 4 & 0.00 & 0.11 & 4 & 16.9 & 0.10 & 4 & 28.0 & 0.21 \\
\hline$M^{*} T$ & 4 & 673.8 & 0.42 & 4 & 0.01 & 0.19 & 4 & 0.00 & 0.45 & 4 & 24.4 & 0.03 & 4 & 39.4 & 0.09 \\
\hline$M^{*} T^{*} D$ & 8 & 681.6 & 0.45 & 8 & 0.01 & 0.11 & 8 & 0.00 & 0.64 & 8 & 20.1 & 0.02 & 8 & 36.6 & 0.06 \\
\hline
\end{tabular}


Tigist Kibru et al.,

Effect of Different Treatments and Their Interaction on Germination Characteristics and Seedling Growth of A. senegal

Analysis of variance results on the effects of individual treatments and their interaction on germination characteristics and seedling growth is shown in Table 7. Sowing depth had a significant effect on germination characteristics and seedling growth. Pre-sowing treatment time had no significant treatment effect on germination characteristics and branch number but it had significant negative effect on seedling height. Substrate media had significant effects on seedling growth but not on germination characteristics. There were no significant interactive treatment effects $\left(M^{*} D, T^{*} D, M^{*} T\right)$ on TGP, PV and MDG. On the other hand, none of the interactions among treatment factors had significant effect on number of branches of seedlings. In fact, seedling height was

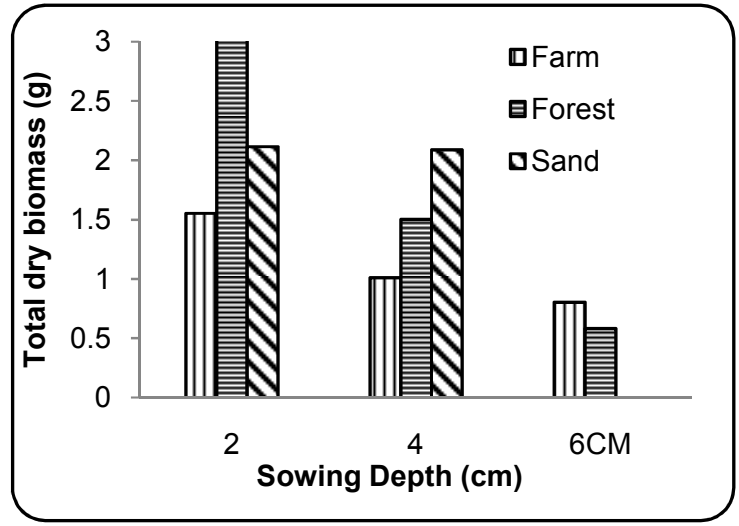

(a)
Sci. Technol. Arts Res. J., July-Sep 2015, 4(3): 47-57 significantly affected by the interactive effects of $M^{\star} T$ and $\mathrm{M}^{*} \mathrm{~T}^{\star} \mathrm{D}$.

Effect of Sowing Depth and Growing Media on Total Dry Biomass of $A$. senegal Seedlings Germinated from Control, $\mathbf{5}$ and 10 Minutes Pre-Treated Seeds.

Sowing depth highly affected the total dry biomass of seedlings grown on different media. Across soil substrates for 10 min pre-treated seeds in boiled water the total dry biomass of the seedlings declined with increasing sowing depth (Figure 7a). The highest total dry biomass was found on forest soil at $2 \mathrm{~cm}$ depth followed by sand and farm soil. The same is true for $5 \mathrm{~min}$ pretreated and control seeds. The highest total dry biomass was found on forest soil at $2 \mathrm{~cm}$ depth followed by sand and farm soil (Figure $7 \mathrm{~b}$ and $7 \mathrm{c}$ ). The total dry biomass was found to be low at $6 \mathrm{~cm}$ depth in all the substrates and no seedling was found survived in $5 \mathrm{mint}$ retreated.

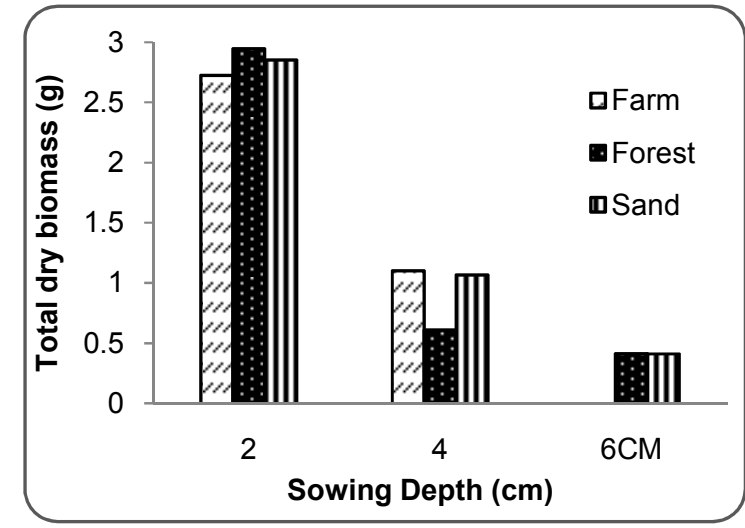

(b)

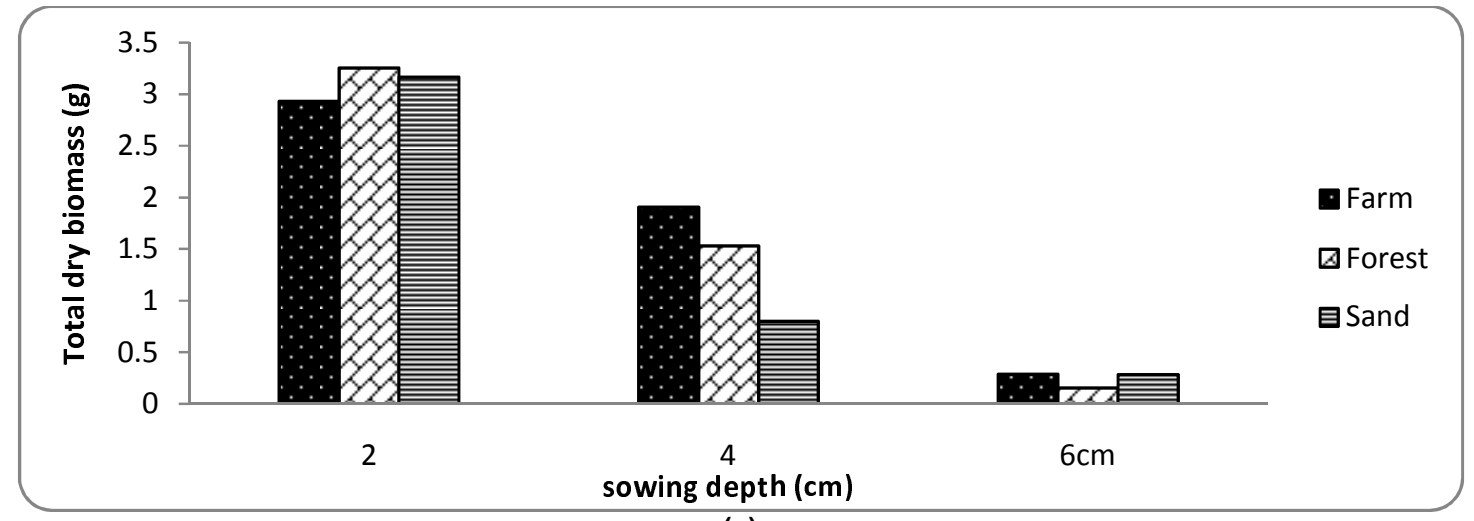

(c)

Figure 7: Total dry biomass of $A$. senegal seedlings germinated from $10 \mathrm{~min}(\mathrm{a})$, and 5 min pre-treated seeds in boiled water (b) and control seeds (c) subsequently sown at different depths in three soil types in a green house

\section{DISCUSSION}

Effect of Sowing Depth on the Germination Characteristics and Seedling Growth of $A$. senegal

The results of this study clearly showed that sowing depth significantly affect the germination characteristics of A. senegal seeds. Mean values across germination characteristics generally declined with increasing sowing depths. The observed decline in germination characteristics with increasing sowing depth might be related to a progressive decline in soil aeration and possibly temperature (Keeley and Fotheringham, 1997; Baskin and Baskin, 2001). Also small seeds cannot easily penetrate the soil and emerge above the soil. In general, seeds buried near the surface germinate with a higher percentage than those buried deeper (Benvenuti et al., 2001). Generally with increasing soil depth, soil aeration and temperature decline which may retard enzyme activation for cellular respiration which digests reserve food to complete seed germination. As research information on the effect of sowing depth on germination of $A$. senegal is lacking, it is difficult to make reasonable comparison of the current finding with data in the literature. However, the results of this study strongly agrees with the findings of Aref (2000) where a significant 
Tigist Kibru et al.,

decline in germination percent was observed with increasing sowing depth in seven Acacia spp. In the same line, Cox and Martin, (1984) reported a higher seedling emergence of $A$. constricta and Prosopis velutina seeds sown at 1 to $2 \mathrm{~cm}$ depths in sandy loam soil. In the same study, germination of seeds decreased at depths greater than $2 \mathrm{~cm}$ even inhibited at $6 \mathrm{~cm}$ depth. A slow and lower seedling emergence was reported for seeds buried deeper than those sown close to the surface in grass species (Cox and Martin, 1984) and in different species (Brandon and Jones, 1998; Gan et al., 2003; Cui et al., 2007).

As in germination characteristics, sowing depth significantly influenced seedling height and number of emerging branches of $A$. senegal seedlings grown on pots filled with different soil substrates. The decline in seedling growth parameters with increasing sowing depth generally reflects the slow rate of seed germination at increasing depths which later translates into a retarded seedling growth rate. Generally, sowing depth that promotes the higher germination percent or faster rate of germination allows early seedling establishment and better seedling growth. Ren et al. (2002) observed that percent seedling emergence, number of days to first emergence and percent seed germination was significantly affected by burial depth.

Effect of Growing Media on the Germination Characteristics and Seedling Growth of $A$. senegal

The result of this study reveals that growing media has no significant effect on the germination characteristics of A. senegal seeds, however forest soil (M2) yielded better germination percent and completeness in seed germination than sand (M3) and farm soil (M1). Among the seeds sown in each media at all depths $62.04 \%$ of seed germination was found for seeds sown on M2, $50.93 \%$ on $\mathrm{M} 3$ and $49.07 \%$ on M1. Also PV was found to be higher in M2 followed by M3. These differences in germination promotion among soil substrates might be related to differences in moisture holding capacity and soil aeration of the different soil substrates. The composition of M2 with high proportion of forest soil might have increased the water holding capacity and improved aeration of the soil. Increased availability of moisture in M2 should have extended imbibition of water by the seeds and improved total germination. Following the same pattern as in germination characteristics, mean values of seedling height and branch number (averaged across pretreatments and depth) were higher for seedlings grown on M2 than M3 or M1. Better seedling growth on M2 could also be the result of better soil physical characteristics (e.g. water holding capacity) and possibly nutrient conditions. Moreover, M2 (with 3:2:1, forest soil: farm soil: sand proportion) should have provided a better soil porosity, together with soil moisture and nutrient, that increased seedling growth. According to Elbrese et al. (2003) appropriate moisture and sufficient aeration are more important for growth performances of seedlings at the early growth stages than the nutrient levels. Kebebew (2007) observed slow growth of C. macrostachys seedlings grown in soil-dung mixture with no sand and attributed the slow seedling growth to low porosity and poor drainage conditions of the soil. In fact variations in growth response to different soil conditions may exist among seedlings of different species. The result of the present study reveals that $A$. senegal seedlings preferred forest soil $>$ sand $>$ farm soil for their growth. Sanchez-
Sci. Technol. Arts Res. J., July-Sep 2015, 4(3): 47-57

Bayo and King (1994) investigated growth of seedlings of three different Acacia species on sand, loam and clay soils. They found out that $A$. horrida prefers loam and sandy soils; $A$. seyal has a similar preference it grows better on sand soils while $A$. nubica responded well in sandy and loam soils.

Effect of Pre-Sowing Seed Treatments on Germination Characteristics and Seedling Growth of $A$. senegal

Pre-sowing treatment of the seeds had no significant effect on the germination characteristics of $A$. senegal seeds. Germination percent (averaged across growth media and sowing depth) of untreated seeds was higher than pre-treated seeds. Of the two pre-treatments $5 \mathrm{~min}$ pre-sowing treatment of the seeds had higher germination than $10 \mathrm{~min}$ pre-treated seeds. The observation that soaking $A$. senegal seeds in boiled water resulted in reduced rate of germination may be related to a partial or permanent damage to seed internal structure and/or metabolic machinery possibly due to longer exposure to boiled water. This observation is in agreement with the findings of Nasroun and Al-Mana (1992) they have showed that boiling water pre-sowing seed treatment of $A$. saligna, A. seyal, A. farnesiana and $A$. tortilis did not increase germination percent significantly. In the same line, Mekuria (1998) reported that untreated (control) seeds of $A$. senegal, $A$. seyal, and $A$. tortilis had significantly higher total germination percent than seeds pre-treated in a boiling water for $1 \mathrm{~min}, 3 \mathrm{~min}$ and $5 \mathrm{~min}$, respectively. Several other studies also confirm that presowing treatment of $A$. senegal seeds at various temperature and various length of time did not enhance germination percentage (e.g. Masamba, 1994; Okunomo and Bosah, 2007). Another study by Danthu et al. (1992) also conform a significantly higher germination percent for untreated $A$. senegal seeds compared to treated seeds in boiling water. In contrast others report that germination percentage of different Acacia species including $A$. senegal improved when soaked in boiling water (Larsen, 1962; Magnani et al., 1993; Demel, 1996; Aref, 2000). For instance Sanyang et al. (2008) reported pre-sowing treatment of $A$. senegal seeds for 10 min had the shortest time to germinate, time to $50 \%$ emergence and the shortest time to last observed emergence also had the highest percentage emergence of $71 \%$. The result of the present study revealed that an increase in soaking time from $5 \mathrm{~min}$ to $10 \mathrm{~min}$ in boiled water reduces the germinability of $A$. senegal seeds. On the other hand, as in germination characteristics, there were no significant effects on branch number of the seedlings but it has negative effect on the height of seedlings. Control seeds have better seedling height than pre-treated seeds. It appears that seed pre-treatment did not improve seed germination but it has affected the growth of the seedlings.

Interactive Effects of Treatment Factors on the Germination Characteristics and Seedling Growth of A. senegal

The lack of significant interactive treatment effects on the germination characteristics and growth of the seedlings except $M^{*} T$ and $M^{*} T^{\star} D$ is difficult to explain. The result of the present study reveals that on the interactions of $M^{*} T$, have negative effect on the growth of the seedlings as the pre-sowing time increases. In other word control seeds sown on different media had highest seedling height than pre-treated seeds sown on different media. Also $M^{*} T^{\star} D$ interaction result reveals that in all 
Tigist Kibru et alo,

media control seeds sown at $2 \mathrm{~cm}$ depth had the highest seedling height. But pre-treated seeds for 5 and $10 \mathrm{~min}$ sown at the same depth had lower seedling height than control seeds.

The result from this study may imply the absence of interactive effects or the complexity of elucidating the mechanism of these interactions under the current experimental conditions. Further research may be required for a better understanding of the interactions among the factors considered in this study.

Effect of Sowing Depth and Growing Media on Total Dry Biomass of $A$. senegal Seedlings Germinated from Control, 5 and 10 Minutes Pre-Treated Seeds

The total dry biomass of the seedlings grown on different media was highly affected by sowing depth. Across soil substrates in both control and pre-treated seeds the highest dry biomass was found from seedlings grown at $2 \mathrm{~cm}$. Seedlings grown at $4 \mathrm{~cm}$ sowing depth has better dry biomass production than $6 \mathrm{~cm}$. There was no seedling survived from seeds sown at $6 \mathrm{~cm}$ depth on sand soil. On the study of Cordazzo, 2007 on different species, $B$. portulacoides seedlings showed high mortality at even low sand burial. Also Ren et al. (2002) reported that deeper the seeds sown in sand, germination and seedling emergence of ten Calligonum $L$. species were lower and slower. This could be due to the seedlings need for nutrient is very low in the sand. This might be the reason for the seedlings mortality in sand soil. Bowers (1996) reported that seeds which are sown deep the soil may die due to exhaustion of food reserves after germination takes place. The same is true in the present study for seeds pre- treated for 5 min in boiled water and sown on farm soil at $6 \mathrm{~cm}$ depth.

The result of the present study reveals that sowing depth has an effect on dry weight production of the seedlings. The seeds which are sown at 4 and $6 \mathrm{~cm}$ depth, their seedlings emerge above the soil slowly and as it is mentioned above due to exhaustion of food reserves the grown seedlings will be weaker or else will die, while the seedlings which are grown from $2 \mathrm{~cm}$ depth emerges faster and this leads the seedlings to produce their food at the right time so they will have better dry weight than the 4 and $6 \mathrm{~cm}$ sown seeds. Also between the soil substrates there was a difference observed in biomass production. This could be due to the nutrient supply of the soil substrates to the seedlings. For example soil substrate constituted in 3:2:1 ratio of soil (forest 3 , farm 2 and sand 1) expected to have higher organic matter content than farm (constituted solely of farm soil) and 3:2:1 (sand 3 , farm 2 and 1 forest) soils.

\section{CONCLUSIONS}

Generally, irrespective of pre-sowing treatments, the highest germination percent and the shortest seedling emergence time were recorded for seeds sown at $2 \mathrm{~cm}$ depth; and decreased germination percent and increased emergence time were observed with increasing sowing depth. Over all, the highest germination of $A$. senegal seeds was obtained from forest soil considering all the treatments and sowing depths together. Among the growing media, forest soil resulted in the best seedling growth and establishment perhaps by being endowed with plant nutrients much better than the rest of the soil types. Considered separately, sand soil gave a higher (100\%) cumulative germination of untreated seeds at $2 \mathrm{~cm}$ depth
Sci. Technol. Arts Res. J., July-Sep 2015, 4(3): 47-57

than the other soil substrates in the shortest time. This means that it could be a good alternative medium for obtaining good germination. Sowing depth highly affected the height and number of branches of $A$. senegal seedlings, $2 \mathrm{~cm}$ depth being the most appropriate for obtaining best seedling growth. It is also concluded that seed pre-treatment is not critical for $A$. senegal as indicated by the performance of the untreated seeds. However, 5 min pre-treatment was the best in farm and forest soils.

\section{Conflict of Interest}

Conflict of Interest none declared.

\section{Acknowledgements}

This study was conducted with financial support, for the first author, from the Ministry of Education (MoA), and University of Hawassa, All are gratefully acknowledged.

\section{REFERENCES}

Abd El-Hafiz, K. (2001). Agroforestry System in Western Sudan, A Case Study of Millet under Acacia albida (Acacia faidherbia). M.Sc. thesis, University of Sanaa, Yemen.

Aref, I.M. (2000). Effects of Pre-Germination Treatments and Sowing Depths upon Germination Potential of Some Acacia Species. Res. Bult., No. (95), Res. Cent. Coll. of Agri., King Saud Univ., pp. (5-17).

Baskin, C.C. and Baskin, J.M. (2001). Seeds: Ecology, Biogeography and Evolution of Dormancy and Germination. Academic Press, California, USA.

Benvenuti, S., Macchia, M., Miele, S. (2001). Light, Temperature and Burial Depth Effects on Rumex Obtussifolius Seed Germination and Emergence. Weed Research 41: 177-186

Brandon, N.J. and Jones, R.M. (1998). The Effect of Sowing Depth and Duration of Watering on Emergence of Tropical Legumes in Clay Soil in Growth Cabinats. Tropical Grasslands 32: 81-88.

Brockwell, J., Bottomley, P.J., Thies, J.E. (1995). Manipulation of Rhizobia Microflora for Improving Legume Productivity and Soil Fertility: A Critical Assessment. Plant Soil 174: 143-180.

Chikamai, B.N. (1996). A Review of Production, Markets and Quality Control of Gum Arabic in Africa. Technical Cooperation Programme. FAO of the United Nations. Project No. TCP/RAF/4557. Rome.

Cordazzo, C.V. (2007). Effects of Salinity and Sand Burial on Germination and Establishment of Blutaparon Portulacoides (St.Hil.) Mears (Amaranthaceae) on Backshore of Southern Brazil. Neotropical Biology and Conservation 2 (2): 94-100.

Cossalter, C. (1987). Introducing Australian Acacias in Dry, Tropical Africa. IN: Australian Acacias in Developing Countries, pp. 119-122. ACIAR, Canberra.

Cox Jerry, R. and Martin Martha, H. (1984). Effects of Planting Depth and Soil Texture on the Emergence of Four Love grasses. Journal of Range Management 37 (3): 204-205.

Cui Jian-yuan, Li Yu-lin, Zhao Ha-lin, Su Yong-zhong \& Drake, S. (2007). Comparison of Seed Germination of Agriophyllum squarrosum (L.) Moq. and Artemisia halodendron Turcz. Ex Bess, Two Dominant Species of 
Tigist Kibru et alo,

Horqin Desert, China. Arid Land Research and Management 21 (3): 165-179.

Czabator, F.J. (1962). Germination Value: An Index Combining Speed and Completeness of Pine Seed Germination. Forest Science 8: 386-396.

Danthu, A., Roussel, J., Saar, J.A. (1992). Effect of Different Pretreatments on the Germination of Acacia senegal Seeds. Seed Science and Technology 20(1): 111-117.

Demel, T. (1996). Germination ecology of twelve indigenous and eight exotic multipuepose leguminous species from Ethiopia. Journal of Forest Ecology and Management 80 (1-3): 209-223.

Food and Agricultural Organization (FAO). (1995). Flavours and Fragrances of Plant Origin. Non-Wood Forest Products, Rome.

Gan, Y.T., Miller, P.R., McDonald, C.L. (2003). Response of Kabuli Chickpea to Seed Size and Planting Depth. Can. Journal of Plant Science 83: 39-46.

Hatab, E.B. (2005). Acacia Conservation, Regeneration and Ecosystem Restoration. Ministry of State for Environmental Affairs Egyptian Environmental Affairs Agency Nature Conservation Sectore St. Katherine protectorate.

Hocking, D. (ed.), (1993). Trees for Drylands. International Science Publisher, New York.

Houerou, H.N. Le, (1980). Chemical Composition and Nutritive Value of Browse in Tropical West Africa. In: Le Houérou, M.N. (ed) Browse in Africa. ILCA, Addis Ababa, pp: 261-289.

Kebebew, W. (2007). Seed germination physiology and nursery establishment of Croton macrostachyus Hocht. Ex. Del. M.Sc. thesis, Addis Ababa University, School of Graduate Studies, 87pp.

Keeley, J.E. and Fotheringham, C.J. (1997). Trace Gas Emission and Smoke-induced Seed Germination. Science 276: $1248-1250$.

Kruger, O. and Mcgavin, G.C. (1998). Insect Species Richness of Acacia Canopies in Mkomazi Game Reserve, North-East Tanzania. Ecography 21: 261-268.

Larsen, E. (1962). Germination Response of Acacia Seeds to Boiling. Australian Journal of Forest Research 1: 51-53.

Loth, Paul E., Boer, Willem F.de., Heitkonig, Ignas M.A., Prins, Herbert H.T. (2005). Germination Strategy of the East African Savanna Tree Acacia tortilis. Journal of Tropical Ecology 21:509-517.

Magnani, G., Macchia, M., Serra, G., Moscheni, E. (1993). Practical Methods for Overcoming Hard Seedness in some Ornamental Acacia Species. Colture-Protette (Italy) 22 (12): 71-78.

Masamba, C. (1994). Presowing Seed Treatments on Four African Acacia Species: Appropriate Technology for Use in Forestry for Rural Development. Forest Ecology and Management 64: 105-109.
Sci. Technol. Arts Res. J., July-Sep 2015, 4(3): 47-57

Maslin, B.R., Miller, J.T., Seigler, D.S. (2003). Overview of the Generic Status of Acacia (Leguminosae: Mimosoideae). Australian Systematic Botany 16(1): 1-18.

Maydell, H.J.V. (1990). Trees and Shrubs of the Sahel: Their Characteristics and Uses. Verlag Josef Margraf, Weikersheim.

Mekuria, A. (1998). Soil Seed Flora, Germination and Regeneration Pattern of the woody species in Arbernosa Acacia woodland. M.Sc.Thesis, ISSN 1402-201X (1998:40) SLU, Sweden.

Milimo, P.B., Dick, J. McP., Munro, R.C. (1994). Domestication of Trees in Semi-Arid East Africa: The Current Situation. In: Leakey, R.R.B., Newton, A.C. (eds.) Tropical Trees: The Potential for Domestication and the Rebuilding of Forest Resources. London, HMSO, 210219. (ITE Symposium, 29).

Nasroun, T.H. and Al-Mana, F.A. (1992). The Effect of PreTreatment of Seeds of Some Arid Zone Species on Their Germination Response. Journal of King Saudi University Agricultural Sciences 4(1): 79-93.

Okunomo, K. and Bosah, B.O. (2007). Germination Response of Acacia senegal (Linn) Seeds to Various Presowing Treatments in the Nursery. Agricultural Journal 2(6): 681-684.

Or, K. and Ward, D. (2003). Three-Way Interactions between Acacia, Large Mammalian Herbivores, and Bruchid Beetles - A Review. African Journal of Ecology 41:257265.

Reid, R.S. and Ellis, J.E., (1995). Impacts of Pastoralists on Woodlands in South Turkana, Kenya: Livestock-Mediated Tree Recruitment. Ecological Applications 5:978-992.

Ren, J., Tao, L., Liu, X.M. (2002). Effect of Sand Burial Depth on Seed Germination and Seedling Emergence of Calligonum L. Species. Journal of Arid Environments 51 (4): 603-611.

Roshetko, J.M. (ed.), (2001). Agroforestry Species and Technologies: A Compilation of the Highlights and Factsheets, Published By NFTA and FACT Net 18951999. ISBN 1573600326 . Winrock International, 38 Winrock Drive, Morrilton, AR.

Sanchez-Bayo, F. and King, G.W. (1994). Imbibition and Germination of Three Acacia Species from Ethiopia South African Journal of Plant and Soil 11(1): 20-25

Sanyang, Sailou E., Kabura, B.H., Huang, Wen-Chi, (2008). Effect of some Pretreatments on Emergence of Acacia senegal (L.). World Journal of Agricultural Sciences 4(2): 213-219.

Springuel, I. and Mekki, A.M. (1994). Economic Value of Desert Plants: Acacia Trees in Wadi Allaqi Biosphere Reserve. Environmental Conservation 21: 41-48.

Wubalem, T., Getachew, D., Alia, R. (2007). Natural Gum and Resin Bearing Species of Ethiopia and their Potential Applications. Investigacion Agraria: Sistemasy Recursos Forestales 16 (3): 211-221. 